\title{
Wytwarzanie zmodyfikowanego aromatycznego plastyfikatora naftowego TDAE
}

\begin{abstract}
Plastyfikatory naftowe można zaliczyć do specyfików naftowych, które znalazły zastosowanie jako jeden ze składników wyrobów kauczukowych i gumowych. Plastyfikatory naftowe i inne produkty naftowe zawierające wielopierścieniowe związki aromatyczne WZA wykazują działanie rakotwórcze i mutagenne. Szczególnie niebezpieczne dla organizmów żywych są wielopierścieniowe węglowodory aromatyczne WWA o potwierdzonym działaniu rakotwórczym i mutagennym. Klasyfikacja plastyfikatorów naftowych, oparta głównie na metodach ich wytwarzania, wyróżnia następujące typy plastyfikatorów: DAE, TDAE, MES, RAE, NAP. Od stycznia 2010 roku na mocy rozporządzenia UE 1907/2007, zwanego powszechnie REACH, wprowadzono zakaz stosowania plastyfikatorów wysokoaromatycznych, co postawiło przed przemysłem naftowym i oponiarskim wyzwanie zastąpienia plastyfikatorów wysokoaromatycznych DAE innymi olejami procesowymi. Plastyfikatory TDAE, spełniające aktualne wymagania w zakresie rakotwórczości, okazują się najlepszą alternatywą dla plastyfikatorów wysokoaromatycznych DAE. Plastyfikatory TDAE są wytwarzane przez wielu producentów produktów naftowych i charakteryzują się dodatnią temperaturą płynięcia. Przedstawiono rodzaje metod technologicznych wytwarzania plastyfikatora TDAE na podstawie rozwiązań patentowych. Opisane zostały również charakterystyki metod procesu odparafinowania rozpuszczalnikowego, jaki jest powszechnie stosowany przy produkcji olejów bazowych mineralnych, głównie grupy I według API, i procesu odolejania gaczów. W badaniach przeprowadzono proces odparafinowania rozpuszczalnikowego klasycznych plastyfikatorów TDAE w celu sprawdzenia możliwości poprawy składu chemicznego w kierunku zwiększenia zawartości atomów węgla w strukturach aromatycznych oraz poprawienia właściwości reologicznych i niskotemperaturowych.
\end{abstract}

Słowa kluczowe: plastyfikatory naftowe, klasyfikacja plastyfikatorów, plastyfikatory TDAE, odparafinowanie rozpuszczalnikowe, wielopierścieniowe węglowodory aromatyczne, mutagenność, kancerogenność plastyfikatorów.

\section{Production of modified petroleum aromatic plasticizers TDAE}

Petroleum plasticizers can be classified as petroleum products that have been used as one of the components of rubber and rubber products. Petroleum plasticizers and other petroleum products containing polycyclic aromatic hydrocarbons WZA, has carcinogenic and mutagenic effects. Particularly dangerous for living organisms are polycyclic aromatic hydrocarbons of PAHs, with proven carcinogenic and mutagenic effects. The classification of plasticizers is based mainly, on the methods of their production. The following types of plasticizers are distinguished: DAE, TDAE, MES, RAE, NAP. Since January 2010, a ban on the use of high-grade plasticizers has been disallowed, which has led to challenges for the oil and tire industry to replace DAE high-performance plasticizers with other process oils. TDAE plasticizers, meeting the current requirements for carcinogenicity, are the best alternative to the highly plasticized DAE plasticizer. TDAE plasticizers are manufactured by many oil product manufacturers and have a positive melt temperature. The types of technological methods of TDAE plasticizer production based on patent solutions are presented. The characteristics of the solvent dewaxing methods that are commonly used in the production of mineral base oils, mainly Group I according to API and the dewaxing process, are also described. The solvent dewaxing of classical TDAE plasticizers was carried out to test the possibility of improving the structural composition of the TDAE plasticizer towards increasing the carbon content of the aromatic structures and improving the rheological and low temperature properties.

Key words: petroleum plasticizers, classification of plasticizers, TDAE plasticizers, solvent dewaxing, polycyclic aromatic hydrocarbons, mutagenicity, carcinogenicity of plasticizers. 


\section{Wstęp}

Plastyfikatory naftowe można zaliczyć do specyfików naftowych, które znalazły zastosowanie jako jeden ze składników wyrobów kauczukowych i gumowych.

Plastyfikatory naftowe $\mathrm{i}$ inne produkty naftowe zawierające wielopierścieniowe związki aromatyczne WZA (ang. PCA - policyclic aromatic compounds) wykazują działanie rakotwórcze i mutagenne. Szczególnie niebezpieczne dla organizmów żywych są wielopierścieniowe węglowodory aromatyczne WWA (ang. PAH - policyclic aromatic hydrocarbons) o potwierdzonym działaniu rakotwórczym i mutagennym $[2,5]$.

Dla prowadzenia i koordynacji badań WWA (PAH) europejski przemysł naftowy w 1963 roku powołał Europejską Organizację Producentów Olejów dla Ochrony Środowiska, Zdrowia i Bezpieczeństwa CONCAWE (The Oil Companies' European Organization for Environment, Heath and Safety). Organizacja CONCAWE wydała szereg publikacji na temat kancerogenności produktów naftowych, w tym ekstraktów aromatycznych stosowanych jako wysokoaromatyczne plastyfikatory do produkcji kauczuków i gum. Postęp w zakresie metod identyfikacji węglowodorów WWA oraz poznanie ich aktywności rakotwórczej doprowadziły do poglądu, że nie sumaryczna ilość związków aromatycznych WZA ekstrahowanych dimetylosulfotlenkiem (DMSO), ale ilość węglowodorów WWA, w tym szczególnie benzo[a]pirenu, i ich wzajemny udział ilościowy decydują o właściwościach rakotwórczych oleju (plastyfikatora) [3].
W Unii Europejskiej, w celu lepszej ochrony środowiska i zdrowia człowieka przed zagrożeniami, jakie mogą stanowić substancje chemiczne, uchwalone zostało przez Parlament Europejski i Radę w dniu 18 grudnia 2006 roku rozporządzenie nr 1907/2006 [33] w sprawie rejestracji, oceny, udzielania zezwoleń i stosowania ograniczeń w zakresie chemikaliów (REACH), które uchyliło dyrektywę 76/769/EEC i przejęło zapisy 27 poprawki, wprowadzające zakaz stosowania ekstraktów wysokoaromatycznych o przekroczonym limicie zawartości wielopierścieniowych węglowodorów aromatycznych. I tak na terenie Unii Europejskiej od 1 stycznia 2010 roku obowiązuje zakaz wprowadzania na rynek i stosowania do produkcji opon samochodowych niektórych olejów aromatycznych zawierających WWA. Zakaz dotyczy również bieżnikowania zużytych opon i części opon przeznaczonych do naprawy opon uszkodzonych, jeżeli zawartość ośmiu WWA wykazujących działanie rakotwórcze przekracza określony poziom. Dopuszczalna zawartość WWA w plastyfikatorach określona jest w sposób następujący: zawartość benzo[a]pirenu nie większa niż $1 \mathrm{mg} / \mathrm{kg}$, a sumaryczna zawartość 8 WWA uznanych za rakotwórcze nie większa niż $10 \mathrm{mg} / \mathrm{kg}$. Ponadto do tych $8 \mathrm{WWA}$ zaliczamy, obok benzo[a]pirenu, następujące związki: benzo[e]piren $(\mathrm{BeP})$, benzo[a]antracen $(\mathrm{BaA})$, chryzen (CHR), benzo[b] fluoranten (BbFA), benzo[j]fluoranten (BjFA), benzo[k]fluoranten (BkFA), dibenzo[a,h]antracen (DBahA).

\section{Podzial plastyfikatorów naftowych i ich właściwości}

Plastyfikatory naftowe dzielą się na aromatyczne, naftenowe i parafinowe, w zależności od udziału węgli w strukturach aromatycznych, naftenowych i parafinowych.

Jedna z klasyfikacji plastyfikatorów naftowych jest oparta głównie na metodach ich wytwarzania. Wyróżnia ona następujące typy plastyfikatorów $[1,4,32]$ :

- DAE (distillate aromatic extract) - ekstrakt aromatyczny uzyskany z destylatu próżniowego ropy naftowej,

- TDAE (treated distillate aromatic extract) - modyfikowany ekstrakt aromatyczny z destylatu próżniowego ropy naftowej,

- MES (mild extraction solvates) - rafinat z łagodnej ekstrakcji rozpuszczalnikowej destylatu próżniowego ropy naftowej,

- RAE (residual aromatic extract) - ekstrakt aromatyczny uzyskany z DAO (deasfaltyzatu) przy produkcji brighstocku,

- TRAE (treated residual aromatic extract) - modyfikowany ekstrakt aromatyczny uzyskany z DAO przy produkcji brighstocku,
- NAP; plastyfikatory naftenowe (naphthenic plasticisers) rafinat z ekstrakcji rozpuszczalnikowej destylatu próżniowego z rop naftenowych, które dzielimy na:

- LNAP - plastyfikatory naftenowe o średniej lepkości,

- HNAP - plastyfikatory naftenowe o wysokiej lepkości.

Plastyfikatory wysokoaromatyczne, otrzymywane jako produkt uboczny w trakcie rafinacji rozpuszczalnikowej destylatów próżniowych z ropy naftowej w procesie wytwarzania olejów bazowych, zyskały duże znaczenie w procesie produkcji opon samochodowych z uwagi na korzystne właściwości użytkowe.

Ponieważ od początku 2010 roku na mocy rozporządzenia UE 1907/2007, zwanego powszechnie REACH [33], wprowadzono zakaz stosowania plastyfikatorów wysokoaromatycznych, przemysł naftowy i oponiarski stanął przed wyzwaniem zastąpienia plastyfikatorów wysokoaromatycznych DAE innymi olejami procesowymi.

W artykułach $[1,6]$ wykazano, że najlepszą alternatywą dla DAE jest plastyfikator TDAE. Mieszanki zawierające TDAE wyróżniają się również najlepszymi właściwościami fizykomechanicznymi w porównaniu z MES i NAP. 
W zgłoszeniu patentowym EP 3031621 A1 [30] firmy The Goodyear Tire \& Rubber Company, pt.: Pneumatic tire, opisano wytwarzanie opony pneumatycznej, w której zastosowano kompozycje kauczuków olejowanych oraz dodanie oleju procesowego bezpośrednio podczas komponowania mieszaniny gumowej.

W rozwiązaniach tego wynalazku zastosowano plastyfikatory typu: MES, TDAE i oleje naftenowe, a więc kompozycja kauczukowa zawiera plastyfikatory o niskim PCA, dzięki czemu nie wykazują one działania rakotwórczego.

Ogólnie plastyfikatory o niskim PCA obejmują te oleje procesowe, których temperatura zeszklenia $\mathrm{Tg}$ mieści się w zakresie od $-40^{\circ} \mathrm{C}$ do $-80^{\circ} \mathrm{C}$. Oleje MES zazwyczaj mają $\mathrm{Tg}$ w zakresie od $-57^{\circ} \mathrm{C}$ do $-63^{\circ} \mathrm{C}$, natomiast oleje TDAE charak- teryzują się $T g$ w zakresie od $-44^{\circ} \mathrm{C}$ do $-50^{\circ} \mathrm{C}$. Ciężkie oleje naftenowe na ogół mają $T g$ w zakresie od $-42^{\circ} \mathrm{C}$ do $-48^{\circ} \mathrm{C}$. $\mathrm{W}$ przedstawionych rozwiązaniach wynalazku zastosowano plastyfikatory typu: MES, TDAE lub naftenowe o ogólnej charakterystyce jakościowej przedstawionej w tablicy 1.

Tablica 1. Właściwości fizykochemiczne plastyfikatorów naftowych

\begin{tabular}{|l|c|c|c|}
\hline \multicolumn{1}{|c|}{ Właściwość } & MES & TDAE & $\begin{array}{c}\text { HNAP } \\
\text { ciężki naftenowy }\end{array}$ \\
\hline Zawartość atomów węgla w strukturach $\mathrm{C}_{\mathrm{A}}[\%]$ & $11 \div 17$ & $25 \div 30$ & $11 \div 17$ \\
\hline Gęstość w temperaturze $15^{\circ} \mathrm{C}\left[\mathrm{g} / \mathrm{cm}^{3}\right]$ & $0,895 \div 0,925$ & $0,930 \div 0,960$ & $0,920 \div 0,950$ \\
\hline Lepkość w temperaturze $40^{\circ} \mathrm{C}\left[\mathrm{mm}^{2} / \mathrm{s}\right]$ & $150 \div 230$ & $370 \div 430$ & $350 \div 720$ \\
\hline Lepkość w temperaturze $100^{\circ} \mathrm{C}\left[\mathrm{mm}^{2} / \mathrm{s}\right]$ & $13 \div 17$ & $16 \div 22$ & $17 \div 33$ \\
\hline Stała lepkościowo-gęstościowa $\mathrm{VGC}$ & $0,825 \div 0,865$ & $0,860 \div 0,890$ & $0,840 \div 0,870$ \\
\hline Intercept refrakcji & $1,495 \div 1,510$ & $1,520 \div 1,540$ & $1,500 \div 1,520$ \\
\hline Temperatura zeszklenia $\mathrm{Tg}\left[{ }^{\circ} \mathrm{C}\right]$ & $-60 \pm 3$ & $-47 \pm 3$ & $-45 \pm 3$ \\
\hline Punkt anilinowy $\left[{ }^{\circ} \mathrm{C}\right]$ & $85 \div 100$ & - & - \\
\hline Temperatura krzepnięcia $\left[{ }^{\circ} \mathrm{C}\right]$ & $<0$ & $<30$ & $<0$ \\
\hline Zaw. WZA (ekstrakt DMSO) $[\%(\mathrm{~m} / \mathrm{m})]$ & $<2,9$ & $<2,9$ & $<2,9$ \\
\hline Temperatura zapłonu (t.o.) $\left[{ }^{\circ} \mathrm{C}\right]$ & 220 & 240 & 240 \\
\hline
\end{tabular}

\section{Producenci plastyfikatorów TDAE, właściwości użytkowe oraz przegląd patentowy metod wytwarzania}

Plastyfikatory naftowe stanowią bardzo istotny składnik wyrobów gumowych i w zasadniczy sposób wpływają na ich właściwości eksploatacyjne [3]. Funkcja zmiękczaczy mineralnych polega między innymi na modyfikacji właściwości fizycznych gumy, szczególnie poprzez poprawę wytrzymałości na rozciąganie, twardości, rozdzierności oraz elastyczności w niskich temperaturach [5]. Przedstawiony powyżej wpływ plastyfikatorów naftowych na właściwości użytkowe wyrobów gumowych w niskich temperaturach oraz próba poprawy składu strukturalnego węglowodorów były inspiracją do badań procesu odparafinowania klasycznego plastyfikatora TDAE.

Plastyfikatory TDAE są wytwarzane przez wielu producentów produktów naftowych i charakteryzują się dodatnią temperaturą płynięcia. Wspomniane plastyfikatory są na rynku dostępne między innymi jako Tudalen SX500 firmy Klaus Dahleke KG, VivaTec 400 i VivaTec 500 firmy H\&R Group, Enerthene 1849 firmy BP, M. Extensoil 1996 firmy Repsol, Quantilus firmy Lotos S.A., Elasticol firmy Orlen S.A., Plaxolene TD 346 firmy Total.

W zgłoszeniu patentowym US 2015/0152253 A1 [31] firmy Synthos S.A., pt.: Functionalized-ESBR with acrylate functional base group, ujawniono różne związki chemiczne pozwalające na uzyskanie kauczuków olejowanych o ulepszonych właściwościach, które zawierają plastyfikator TDAE. W wynalazku emulsyjne kauczuki styren-butadien (FE-SBR) zawierają w grupie funkcyjnej FE-SBR estry lub akrylany. Kauczuk
FE-SBR skutecznie miesza się $\mathrm{w}$ formulacjach $\mathrm{z}$ preparatami na bazie krzemionki, co daje lepsze właściwości w wyrobach gumowych, szczególnie takich jak opony samochodowe. Według opisu tego patentu jakość kompozycji kauczukowej i gumowej badana jest na podstawie wytrzymałości na rozciąganie (wyższa jest lepsza), energii do zerwania (wyższa jest lepsza), odporności na starzenie (wyższa jest lepsza) i złożonej temperatury zeszklenia (niższa jest lepsza).

Poniżej przedstawiono przegląd metod wytwarzania plastyfikatora TDAE (treated distillate aromatic extract) $\mathrm{w}$ oparciu o rozwiązania patentowe, spełniającego wymagania stawiane plastyfikatorom nierakotwórczym w zakresie zawartości związków aromatycznych PCA i PAH zgodnie z rozporządzeniem REACH.

Przykłady rafinacji selektywnej ekstraktu aromatycznego z destylatu próżniowego w kolumnie ekstrakcyjnej przy użyciu furfurolu jako ekstrahenta przedstawia opis patentowy DE 3930422 [11]. Rafinację selektywną z dwustopniowym wydzieleniem rafinatu $\mathrm{z}$ roztworu ekstraktu aromatycznego w furfurolu, poprzez obniżenie temperatury, przedstawia opis patentowy EP 839891 [14]. W opisie tym podano przykłady rafinacji furfurolem ekstraktu aromatycznego uzyskanego z destylatu próżniowego oraz odasfaltowanej pozostałości próżniowej ropy naftowej.

Procesy mieszane rafinacji selektywnej ekstraktu aromatycznego z destylatu próżniowego, a następnie rafinacji wodorem 
ujawniają opisy patentowe: DE 2343238 [8] i EP 1106673 [12]. W charakterze ekstrahenta w procesie według zgłoszenia DE 2343238 stosowany jest furfurol, a według zgłoszenia EP 1106673 - N-metylopirolidon.

Proces hydrorafinacji prowadzący do uwodornienia policyklicznych węglowodorów aromatycznych w mieszaninie ekstraktu aromatycznego z destylatu próżniowego z destylatem próżniowym ropy naftowej przy użyciu katalizatorów $\mathrm{Ni}-\mathrm{Mo} / \mathrm{Al}_{2} \mathrm{O}_{3} \mathrm{i} \mathrm{Ni}-\mathrm{Co}-\mathrm{Mo} / \mathrm{Al}_{2} \mathrm{O}_{3}$ zawarty jest w opisie patentowym EP 1260569 [13].

W opisach patentowych przedstawione są ekstrakty o zróżnicowanych właściwościach. Dla ekstraktu aromatycznego z rafinacji selektywnej destylatu próżniowego zawartość PCA wynosi od 16\% według opisu patentowego EP 839891, natomiast do 29\% według opisu patentowego EP 1106673. Dla ekstraktu z rafinacji selektywnej odasfaltowanej pozostałości próżniowej według opisu patentowego EP 839891 zawartość PCA wynosi 5,5\%.

W opisie patentowym PL 207051 [21] przedstawiono wytworzenie plastyfikatora TDAE w wyniku rafinacji selektywnej ekstraktu aromatycznego z destylatu próżniowego; uzyskano rafinat o niskim poziomie WWA (wielopierścieniowych węglowodorów aromatycznych), który jest komponowany w odpowiedniej proporcji z plastyfikatorem RAE (residual aromatic extract). Opis patentowy PL 224956 [25] dotyczy udoskonalenia sposobu wytwarzania plastyfikatora naftowego do kauczuku i gumy według patentu PL 207051 , polegającego na rozszerzeniu o frakcję zaciemnioną surowca podlegającego odasfaltowaniu propanem i zastosowaniu uzyskanego ekstraktu jako kolejnego składnika do wytworzenia plastyfikatora.

W opisach patentowych PL 207052 [22] i PL 207056 [23] przedstawiono wytworzenie plastyfikatora TDAE w wyniku rafinacji selektywnej z destylatu próżniowego w kolum- nie ekstrakcyjnej przy użyciu furfurolu i następnie ponownej rafinacji furfurolem uzyskanego rafinatu o niskim poziomie WWA - otrzymany pożądany ekstrakt aromatyczny jest komponowany w odpowiedniej proporcji z plastyfikatorem RAE lub poddany destylacji próżniowej na frakcje, a uzyskane frakcje komponowane są dla osiągnięcia wymaganej jakości plastyfikatora naftowego do kauczuku i gumy.

Patent PL 208531 [24] dotyczy wytwarzania plastyfikatora aromatycznego zawierającego poniżej 3\% PCA. Sposób wytwarzania plastyfikatora polega na poddaniu ekstraktu działaniu polarnego rozpuszczalnika dimetylosulfotlenku w stosunku wagowym polarnego rozpuszczalnika do ekstraktu w granicach $(2,0 \div 4,0): 1$, w temperaturze pomiędzy $30^{\circ} \mathrm{C}$ i $120^{\circ} \mathrm{C}$, i zastosowaniu otrzymanego rafinatu jako plastyfikatora aromatycznego.

Zgłoszenie patentowe WO 2011098096 A1 [32] dotyczy produkcji olejów procesowych z rafinacji olejów mineralnych z ulepszonymi właściwościami, przy czym metoda ta obejmuje ekstrakcję ekstraktu RAE uzyskanego przy rafinacji DAO (deasphalted oil) w celu wytwarzania brightstocku albo mieszaniny ekstraktów, która składa się z ekstraktu brightstock TRAE i jednego albo większej liczby olejów procesowych DAE, TDAE i MES.

W wyniku zastosowanych rozwiązań otrzymywany jest olej procesowy z zawartością policyklicznych związków aromatycznych $\leq 3 \%(\mathrm{~m} / \mathrm{m})$, który może być użyty jako plastyfikator do kauczuków i ich mieszanin.

Opisane wcześniej plastyfikatory naftowe TDAE charakteryzują się dodatnią temperaturą płynięcia, co jest cechą mogącą oddziaływać niekorzystnie na elastyczność wyrobów gumowych w niskich temperaturach, a więc w przypadku pozytywnego wpływu procesu odparafinowania można oczekiwać obniżenia temperatury płynięcia tych plastyfikatorów i poprawić ich działanie użytkowe w niskich temperaturach.

\section{Charakterystyka metod procesu odparafinowania rozpuszczalnikowego}

Proces odparafinowania rozpuszczalnikowego jest powszechnie stosowany przy produkcji olejów bazowych mineralnych, głównie grupy I według API.

W historycznym zarysie w procesach rozpuszczalnikowego odparafinowania olejów i odolejania gaczów wykorzystywano różnego rodzaju związki chemiczne oraz rozpuszczalniki organiczne takie jak: ditlenek siarki i benzen; benzol i aceton oraz toluen i aceton; propan; trichloroetylen (tri) - (metoda separator - Nobel); dichloroetan - benzen (metoda Barisol); mocznik (karbamid); eter metylo-tert-butylowy (MTBE).

Proces benzen-aceton ostatecznie przekształcił się w procesy wykorzystujące mieszaniny ketonów z węglowodorami aromatycznymi, np. metyloetyloketonu z toluenem (MEK-TOL), lub mieszaniny ketonów, np. metyloetyloketonu z metyloizobutyloketonem (MEK/MIBK). Procesy z zastosowaniem obu mieszanin rozpuszczalników są podobne, ale różnią się sposobem chłodzenia oraz odzyskiem rozpuszczalników z procesu. Są to najbardziej rozpowszechnione procesy odparafinowania rozpuszczalnikowego na świecie, używane w produkcji olejów bazowych i odolejania gaczów. Oprócz odparafinowania $\mathrm{z}$ użyciem ketonów stosowane są procesy odparafinowania mieszaniną rozpuszczalników chlorowcopochodnych: dichloroetanu i dichlorometanu (Di/Me) oraz propanem.

Technologia procesu rozpuszczalnikowego odparafinowania ketonami zamieszczona w opisach wynalazków objętych patentami DE 2827494 [10] i US 3972779 [26] opiera się na 
odparafinowaniu oleju rozpuszczalnikiem ketonowym, będącym mieszaniną metyloetyloketonu i toluenu, na drodze stopniowego rozcieńczania wsadu. Zastosowanie rozpuszczalnika o typowym składzie - MEK $60 \%$, a toluen $40 \%$ - powoduje, że w temperaturze filtracji olej jest nadal dobrze rozpuszczalny w mieszaninie rozpuszczalników, a wosk nie. Wielkość rozcieńczeń wyrażona stosunkiem rozpuszczalnika do oleju wynosi od 1:1 do 4:1, w zależności od lepkości surowca. Ciężkie i pozostałościowe wsady olejowe wymagają stosowania większych rozcieńczeń w ciągu chłodzenia.

W opisie patentowym US 4146461 [27] przedstawiono modyfikację procesu MEK, wprowadzając oryginalną metodę krystalizacji wosków w krystalizatorze typu Dilchill. Proces może być stosowany dla surowców o szerokim zakresie lepkości. Typowymi dla tego procesu rozpuszczalnikami są mieszaniny metyloetyloketonu i metyloizobutyloketonu (MEK/MIBK) lub metyloetyloketonu i toluenu (MEK-TOL). Proces polega na bezpośrednim wtryskiwaniu zimnego rozpuszczalnika do gorącego surowca w środowisku intensywnego, dynamicznego mieszania. Typowy stosunek objętościowy rozpuszczalnika do surowca $w$ procesie odparafinowania wynosi od 2,5:1 do 6:1, w zależności od właściwości surowca.

W opisach patentowych DE 2753163 [48] i GB 1155695 [9] ujawniono proces odparafinowania Di/Me, który opiera się na wysokiej selektywności rozpuszczalnika. Rozpuszczalnikiem jest mieszanina dichloroetanu i dichlorometanu. Dla lekkich i średnich destylatów (rafinatów) optymalny stosunek Di:Me wynosi 50:50, dla destylatów pozostałościowych (brightstocku) 35:65. Ilość rozpuszczalnika użytego do odparafinowania wynosi zwykle od $400 \div 700 \%$ obj. w odniesieniu do surowca.
W opisie patentowym US 4375403 [28] przedstawiono proces odparafinowania propanem, który najlepiej sprawdza się w odparafinowaniu ciężkich destylatów olejowych, ale w przypadku lekkich frakcji również zapewnia dobre rezultaty. Ilość rozcieńczalnika zależy od lepkości surowca, stosunek propanu do surowców lekkich wynosi 1,5:1 i rośnie do 3:1 w przypadku ciężkich frakcji.

W opisie patentowym US 4444648 [29] zaprezentowano proces odparafinowania surowców olejowych z zastosowaniem eteru metylo-tert-butylowego, względnie jego mieszanin z innymi antyrozpuszczalnikami, np. niskocząsteczkowym ketonem lub chlorowcopochodną alifatyczną. Na podstawie badań ustalono, że najefektywniejszą kompozycją rozpuszczalnikową jest mieszanina metyloetyloketonu $\mathrm{z}$ eterem metylo-tert-butylowym o składzie 60\% (V/V) MEK i 40\% (V/V) MTBE. Zgodnie $\mathrm{z}$ opatentowanym rozwiązaniem $\mathrm{w}$ procesie odparafinowania jako surowce olejowe można stosować różnego rodzaju frakcje naftowe umożliwiające wytwarzanie olejów bazowych.

W opisach patentowych PL 141875 [16] i PL 162782 [19] przedstawiono proces odparafinowania rozpuszczalnikowego surowców olejowych z destylacji próżniowej parafinowej ropy naftowej z dodatkiem modyfikatora krystalizacji.

W opisach patentowych PL 151667 [17] i PL 188731 [20] zaprezentowano proces odparafinowania rozpuszczalnikowego surowców olejowych z destylacji próżniowej ropy naftowej.

W opisie patentowym PL 161658 [18] przedstawiono proces odolejania rozpuszczalnikowego gaczów parafinowych uzyskanych w procesach rafinacji rozpuszczalnikowej i odparafinowania rozpuszczalnikowego na bloku olejowym.

\section{Opis laboratoryjnego procesu odparafinowania rozpuszczalnikowego}

Krystalizację węglowodorów stałych w laboratorium prowadzi się metodą stopniowego oziębiania mieszaniny oleju z rozpuszczalnikiem znajdującej się w krystalizatorze. Krystalizator umieszczony jest w łaźni chłodzącej, wyposażonej w programator cyklu chłodzenia, pozwalający na ustalenie końcowej temperatury krystalizacji oraz odpowiedniej szybkości schładzania w kolejnych etapach procesu. Do kriostatu podłączona jest nucza filtracyjna, wyposażona w płaszcz, w którym krąży czynnik chłodzący.

Proces krystalizacji prowadzony jest metodą rozcieńczeń, poprzez dodawanie do schładzanej mieszaniny surowca z rozpuszczalnikiem kolejnych porcji oziębionego rozpuszczalnika w odpowiednich momentach cyklu schładzania. Pierwszą porcję rozpuszczalnika do surowca wprowadza się w temperaturze, w której surowiec jest jednorodną fazą ciekłą niezawierającą kryształów. Natomiast w punkcie dostrzyku do mieszaniny temperatura rozpuszczalnika ma być taka, aby zapobiegała zakłóceniu procesu krystalizacji węglowodorów w mieszaninie.

W procesie krystalizacji stosuje się ciągłe mieszanie zawartości krystalizatora za pomocą mieszadła z końcówką kotwiczną, o szybkości mieszania dostosowanej do zwiększającej się lepkości mieszaniny.

Po osiągnięciu końcowej temperatury krystalizacji następuje odfiltrowanie wydzielonych węglowodorów stałych, zawierających zaokludowany rozpuszczalnik, od roztworu oleju na nuczy próżniowej. Roztwór oleju (filtrat) gromadzi się w odbieralniku. Odfiltrowane węglowodory stałe przemywa się porcją zimnego rozpuszczalnika. Zebrane z nuczy węglowodory stałe,a także filtrat poddaje się procesowi regeneracji rozpuszczalnika. Operacja regeneracji rozpuszczalnika prowadzona jest metodą destylacji ze strippingiem azotem. 


\section{Surowce do badania procesu odparafinowania rozpuszczalnikowego}

Surowcami do badania procesu odparafinowania były plastyfikatory TDAE, pochodzące z przerobu ciężkich ekstraktów na instalacji selektywnej rafinacji rozpuszczalnikowej. Właściwości fizykochemiczne ciężkich ekstraktów przedstawiono w tablicy 2, a właściwości fizykochemiczne próbek uzyskanych plastyfikatorów zamieszczono w tablicy 3 .

Surowiec do badań procesu odparafinowania (oznaczenie próbki 925/Bl) uzyskany z Ekstraktu 1 miał lepkość kinematyczną w temperaturze $100^{\circ} \mathrm{C}$ wynoszącą $22,29 \mathrm{~mm}^{2} / \mathrm{s}$, zawar- tość atomów węgla w strukturach aromatycznych na poziomie 23,86\%, zawartość WZA (ekstrakt DMSO) 1,9\% $(\mathrm{m} / \mathrm{m})$, zawartość WWA $4,2 \mathrm{mg} / \mathrm{kg}$ oraz temperaturę płynięcia $+30^{\circ} \mathrm{C}$. Surowiec (oznaczenie próbki 48/Bl) uzyskany z Ekstraktu 2 miał lepkość kinematyczną w temperaturze $100^{\circ} \mathrm{C}$ wynoszącą $24,47 \mathrm{~mm}^{2} / \mathrm{s}$, zawartość atomów węgla w strukturach aromatycznych na poziomie $25,84 \%$, zawartość WZA (ekstrakt DMSO) 2,4\% ( $\mathrm{m} / \mathrm{m})$, zawartość WWA 4,6 mg/kg oraz temperaturę płynięcia $+28^{\circ} \mathrm{C}$.

Tablica 2. Właściwości fizykochemiczne surowców

\begin{tabular}{|c|c|c|c|}
\hline Właściwości & $\begin{array}{l}\text { Surowiec; } \\
\text { Ekstrakt } 1\end{array}$ & $\begin{array}{l}\text { Surowiec; } \\
\text { Ekstrakt } 2\end{array}$ & Metody badań \\
\hline Gęstość w temperaturze $20^{\circ} \mathrm{C}\left[\mathrm{g} / \mathrm{cm}^{3}\right]$ & 0,9893 & 0,9916 & PN-EN ISO 12185 \\
\hline Lepkość kinematyczna w temperaturze $50^{\circ} \mathrm{C}\left[\mathrm{mm}^{2} / \mathrm{s}\right]$ & 739,31 & 783,53 & PN-EN ISO 3104 \\
\hline Temperatura zapłonu (t.o.) $\left[{ }^{\circ} \mathrm{C}\right]$ & 279 & 281 & PN-EN ISO 2592 \\
\hline Współczynnik załamania światła $\mathrm{n}_{\mathrm{D}}{ }^{20}$ & 1,5614 & 1,5648 & PN-C-04952 \\
\hline Zawartość siarki $[\%(\mathrm{~m} / \mathrm{m})]$ & 3,22 & 3,35 & PN-EN ISO 8754 \\
\hline Temperatura płynięcia $\left[{ }^{\circ} \mathrm{C}\right]$ & +26 & +25 & PN-ISO 3016 \\
\hline Zawartość WZA (ekstrakt DMSO) [\% $(\mathrm{m} / \mathrm{m})]$ & 12,8 & 13,0 & IP 346 \\
\hline $\begin{array}{l}\text { Zawartość atomów węgla w strukturach [\%]: } \\
-\mathrm{C}_{\mathrm{A}} \\
-\mathrm{C}_{\mathrm{N}} \\
-\mathrm{C}_{\mathrm{P}}\end{array}$ & $\begin{array}{l}35,33 \\
15,04 \\
49,63\end{array}$ & $\begin{array}{l}36,85 \\
12,29 \\
50,86\end{array}$ & ASTM D 2140 \\
\hline $\begin{array}{l}\text { Zawartość WWA [mg/kg]: } \\
\text { - benzo[a]piren } \\
\text { - benzo[e]piren } \\
\text { - benzo[a]antracen } \\
\text { - chryzen } \\
\text { - benzo[b,j,k]fluoranten } \\
\text { - dibenzo[a,h]antracen }\end{array}$ & $\begin{array}{r}7,3 \\
25,8 \\
2,4 \\
27,4 \\
14,7 \\
2,3\end{array}$ & $\begin{array}{r}6,8 \\
24,9 \\
2,3 \\
18,7 \\
14,3 \\
1,8\end{array}$ & Met. GC/MS \\
\hline Suma & 79,9 & 68,8 & \\
\hline
\end{tabular}

Tablica 3. Właściwości fizykochemiczne plastyfikatorów TDAE

\begin{tabular}{|c|c|c|c|}
\hline Właściwości & \multicolumn{2}{|c|}{ Plastyfikator TDAE } & Metody badań \\
\hline Nr ewidencyjny & 925/B1 & 48/B1 & - \\
\hline Gęstość w temperaturze $20^{\circ} \mathrm{C}\left[\mathrm{g} / \mathrm{cm}^{3}\right]$ & 0,9478 & 0,9541 & PN-EN ISO 12185 \\
\hline Lepkość kinematyczna w temperaturze $100^{\circ} \mathrm{C}\left[\mathrm{mm}^{2} / \mathrm{s}\right]$ & 22,29 & 24,47 & PN-EN ISO 3104 \\
\hline Temperatura zapłonu (t.o.) $\left[{ }^{\circ} \mathrm{C}\right]$ & 276 & 271 & PN-EN ISO 2592 \\
\hline Współczynnik załamania światła $\mathrm{n}_{\mathrm{D}}{ }^{20}$ & 1,5302 & 1,5349 & PN-C-04952 \\
\hline Zawartość siarki $[\%(\mathrm{~m} / \mathrm{m})]$ & 2,68 & 3,04 & PN-EN ISO 8754 \\
\hline Temperatura płynięcia $\left[{ }^{\circ} \mathrm{C}\right]$ & +30 & +28 & PN-ISO 3016 \\
\hline Zaw. WZA (ekstrakt DMSO) [\% $(\mathrm{m} / \mathrm{m})]$ & 1,9 & 2,4 & IP 346 \\
\hline $\begin{array}{l}\text { Zawartość atomów węgla w strukturach [\%]: } \\
-\mathrm{C}_{\mathrm{A}} \\
-\mathrm{C}_{\mathrm{N}} \\
-\mathrm{C}_{\mathrm{P}}\end{array}$ & $\begin{array}{l}23,86 \\
19,14 \\
56,99\end{array}$ & $\begin{array}{l}25,84 \\
16,49 \\
57,67\end{array}$ & ASTM D 2140 \\
\hline
\end{tabular}


cd. Tablica 3

\begin{tabular}{|c|c|c|c|}
\hline Właściwości & Plastyfikator TDAE & Plastyfikator TDAE & Metody badań \\
\hline $\begin{array}{l}\text { Zawartość WWA [mg/kg]: } \\
\text { - benzo[a]piren } \\
\text { - benzo[e]piren } \\
\text { - benzo[a]antracen } \\
\text { - chryzen } \\
\text { - benzo[b]fluoranten } \\
\text { - benzo[j]fluoranten } \\
\text { - benzo[k]fluoranten } \\
\text { - dibenzo[a,h]antracen }\end{array}$ & $\begin{array}{l}0,7 \\
0,9 \\
0,3 \\
1,1 \\
1,2 \\
0,1\end{array}$ & $\begin{array}{l}0,7 \\
0,9 \\
0,4 \\
1,2 \\
1,4 \\
0,1\end{array}$ & Met. GC/MS \\
\hline Suma WWA & 4,2 & 4,6 & \\
\hline
\end{tabular}

\section{Procesy odparafinowania rozpuszczalnikowego MEK-TOL i DI/ME}

Próbki rafinatów TDAE poddano procesowi odparafinowania rozpuszczalnikowego przez dwa różne rodzaje rozpuszczalników stosowane powszechnie w przemyśle: MEK-TOL i DI/ME. Do przeprowadzenia procesów odparafinowania rozpuszczalnikowego na instalacji laboratoryjnej wybrano parametry technologiczne podobne do parametrów pracy instalacji przemysłowych.

Dodatkowo wprowadzano modyfikator lepkości z firmy Evonik Industries o nazwie handlowej VISCOPLEX 9-350 oraz wzięto pod uwagę doświadczenia INiG - PIB w pro- wadzeniu rozpuszczalnikowych procesów odparafinowania i zrezygnowano z mycia w temperaturze sączenia dla części prób badawczych.

Zastosowane parametry technologiczne zamieszczono w tablicach wraz z bilansami masowymi oraz właściwościami deparafinatów i gaczów uzyskanych z procesów odparafinowania. Wyjściowy wsad destylatu próżniowego w procesie odparafinowania wynosił $300 \mathrm{~g}$ dla wszystkich przeprowadzonych prób. Modyfikator krystalizacji dozowano w ilości $1000 \mathrm{ppm}(\mathrm{mg} / \mathrm{kg})$ zgodnie z zaleceniami producenta.

\section{Wyniki badań odparafinowania rozpuszczalnikiem MEK-TOL plastyfikatora TDAE}

Procesy odparafinowania rozpuszczalnikiem MEK-TOL próbek surowca plastyfikatora TDAE 925/B1 i 48/Bl przedstawiono w tablicy 4.

W tablicy 4 przedstawione zostały również parametry technologiczne, bilans masowy oraz właściwości uzyskanych deparafinatów i gaczów dla 6 procesów odparafinowania MET-TOL próbki surowca 925/Bl i dla 1 procesu odparafinowania próbki surowca 48/Bl.

Podstawowe parametry technologiczne były następujące: stosunek masowy MEK-TOL zawierał się w przedziale od 40:60 do 60:40, temperatura krystalizacji wynosiła $-20^{\circ} \mathrm{C}$ lub $-28^{\circ} \mathrm{C}$, całkowity stosunek rozpuszczalnika do frakcji wynosił

Tablica 4. Parametry technologiczne, bilans masowy oraz właściwości deparafinatów i gaczów uzyskanych z procesów odparafinowania MEK-TOL próbek surowca 925/Bl i 48/Bl

\begin{tabular}{|l|c|c|c|c|c|c|c|c|}
\hline \multicolumn{1}{|c|}{ Nr odparafinowania } & 17 & 22 & 25 & 27 & 34 & 35 \\
\hline Surowiec, nr próbki & $925 / \mathrm{Bl}$ & $925 / \mathrm{Bl}$ & $925 / \mathrm{B} 1$ & $925 / \mathrm{Bl}$ & $925 / \mathrm{Bl}$ & $925 / \mathrm{Bl}$ & $48 / \mathrm{Bl}$ \\
\hline Modyfikator lepkości & - & $\begin{array}{c}\text { Viscoplex } \\
9-350\end{array}$ & - & - & - & - \\
\hline \multicolumn{1}{|c|}{ Parametry technologiczne procesów odparafinowania } \\
\hline
\end{tabular}


cd. Tablica 4

\begin{tabular}{|c|c|c|c|c|c|c|c|}
\hline $\mathrm{Nr}$ odparafinowania & 17 & 22 & 25 & 27 & 34 & 35 & 37 \\
\hline \multicolumn{8}{|c|}{ Właściwości deparafinatu } \\
\hline Lepkość kinematyczna w temp. $10^{\circ} \mathrm{C}\left[\mathrm{mm}^{2} / \mathrm{s}\right]$ & 12702 & 12845 & 12946 & 12815 & 12578 & 12804 & 13018 \\
\hline Lepkość kinematyczna w temperaturze $100^{\circ} \mathrm{C}\left[\mathrm{mm}^{2} / \mathrm{s}\right]$ & 23,80 & 23,09 & 24,17 & 24,73 & 25,27 & 24,78 & 27,13 \\
\hline Współczynnik załamania światła $\mathrm{n}_{\mathrm{D}}{ }^{20}$ & 1,5331 & 1,5335 & 1,5330 & 1,5331 & 1,5330 & 1,5334 & 1,5175 \\
\hline Gęstość w temperaturze $20^{\circ} \mathrm{C}\left[\mathrm{g} / \mathrm{cm}^{3}\right]$ & 0,9524 & 0,9528 & 0,9563 & 0,9527 & 0,9563 & 0,9528 & 0,9524 \\
\hline Zawartość siarki $[\%(\mathrm{~m} / \mathrm{m})]$ & 2,74 & 3,22 & 3,15 & 3,08 & 3,16 & 3,13 & 3,20 \\
\hline Zaw. WZA (ekstrakt DMSO) $[\%(\mathrm{~m} / \mathrm{m})]$ & - & - & 2,1 & 2,1 & 2,1 & 2,1 & 2,6 \\
\hline $\begin{array}{l}\text { Zawartość atomów węgla w strukturach [\%]: } \\
-\mathrm{C}_{\mathrm{A}} \\
-\mathrm{C}_{\mathrm{N}} \\
-\mathrm{C}_{\mathrm{P}}\end{array}$ & $\begin{array}{l}24,87 \\
19,39 \\
55,74\end{array}$ & $\begin{array}{l}24,58 \\
17,66 \\
57,76 \\
\end{array}$ & $\begin{array}{l}24,09 \\
18,41 \\
57,50 \\
\end{array}$ & $\begin{array}{l}24,32 \\
17,63 \\
58,09 \\
\end{array}$ & $\begin{array}{l}24,34 \\
18,61 \\
57,45\end{array}$ & $\begin{array}{l}24,37 \\
17,60 \\
58,04\end{array}$ & $\begin{array}{l}26,21 \\
16,84 \\
56,95\end{array}$ \\
\hline Temperatura płynięcia $\left[{ }^{\circ} \mathrm{C}\right]$ & -15 & -15 & -15 & -15 & -14 & -15 & -13 \\
\hline \multicolumn{8}{|c|}{ Właściwości gaczu } \\
\hline Współczynnik załamania światła $\mathrm{n}_{\mathrm{D}}{ }^{70}$ & 1,4548 & 1,4522 & 1,4900 & 1,4880 & 1,4749 & 1,4712 & 1,4768 \\
\hline Temperatura krzepnięcia $\left[{ }^{\circ} \mathrm{C}\right]$ & 59,0 & 60,0 & 52,8 & 53,0 & 52,4 & 57,1 & 52,4 \\
\hline Zawartość oleju [\% $(\mathrm{m} / \mathrm{m})]$ & 8,68 & 4,73 & 73,83 & 62,0 & 32,1 & 21,0 & 58,7 \\
\hline
\end{tabular}

od 4,8:1 do 11:1. W próbie nr 22 zastosowano do procesu modyfikator krystalizacji.

W próbach odparafinowania uzysk deparafinatu był duży i wynosił od 84,0 do 98,0\% ( $\mathrm{m} / \mathrm{m})$, a uzysk gaczu zawierał się w przedziale od 1,0 do $12,0 \%(\mathrm{~m} / \mathrm{m})$.

W porównaniu do surowca 925/B1 w wyniku procesu odparafinowania w deparafinacie TDAE dla wszystkich wykonanych prób zaobserwowano wzrost zawartości atomów węgla w strukturach aromatycznych, który wynosił od 0,23\% do $1,01 \%$, zawartość atomów węgla w strukturach naftenowych wzrosła maksymalnie do 0,25\% lub zmniejszała się do maksymalnie 1,54\%, natomiast zawartość atomów węgla w strukturach parafinowych uległa zmniejszeniu do maksymalnie $1,26 \%$ lub wzrastała do maksymalnie $1,1 \%$.

We wszystkich próbach odparafinowania w deparafinacie nastąpiło znaczące obniżenie temperatury płynięcia, do około $-15^{\circ} \mathrm{C}$, w porównaniu do surowca, którego temperatura płynięcia wynosiła $+30^{\circ} \mathrm{C}$.

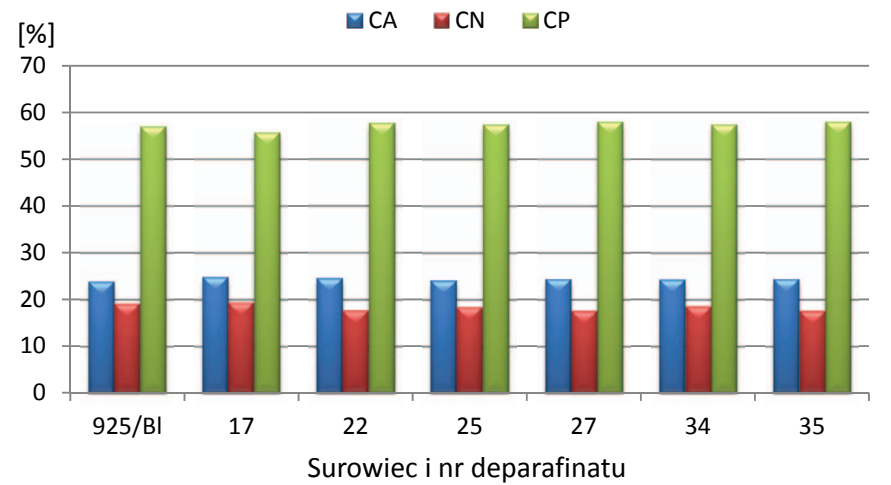

Rys. 1. Wpływ procesu odparafinowania rozpuszczalnikiem MEK-TOL na zmianę składu strukturalnego deparafinatów
Na gaczach uzyskanych w próbach odparafinowania wykonano badania laboratoryjne w zakresie trzech parametrów jakościowych. W porównaniu do deparafinatów i surowca w przypadku gaczów wyraźnie zmniejszyła się wartość współczynnika załamania światła oraz wyraźnie wzrosła temperatura krzepnięcia, co wskazuje na zachowanie selektywności procesu odparafinowania rafinatu TDAE.

W jednej próbie odparafinowania surowca 48/Bl uzysk deparafinatu wynosił 95,0\% $(\mathrm{m} / \mathrm{m})$, a uzysk gaczu 3,0\% $(\mathrm{m} / \mathrm{m})$.

W porównaniu do surowca 48/B1 w wyniku procesu odparafinowania w deparafinacie TDAE zaobserwowano wzrost zawartości atomów węgla w strukturach aromatycznych, który wynosił $0,37 \%$. W deparafinacie nastąpiło znaczące obniżenie temperatury płynięcia, do $-13^{\circ} \mathrm{C}$, w porównaniu do surowca (plastyfikatora TDAE).

Ilustrację graficzną wpływu procesu odparafinowania dla wsadu 925/B1 na zmianę składu strukturalnego i temperatury płynięcia deparafinatów przedstawiono na rysunkach 1-2.

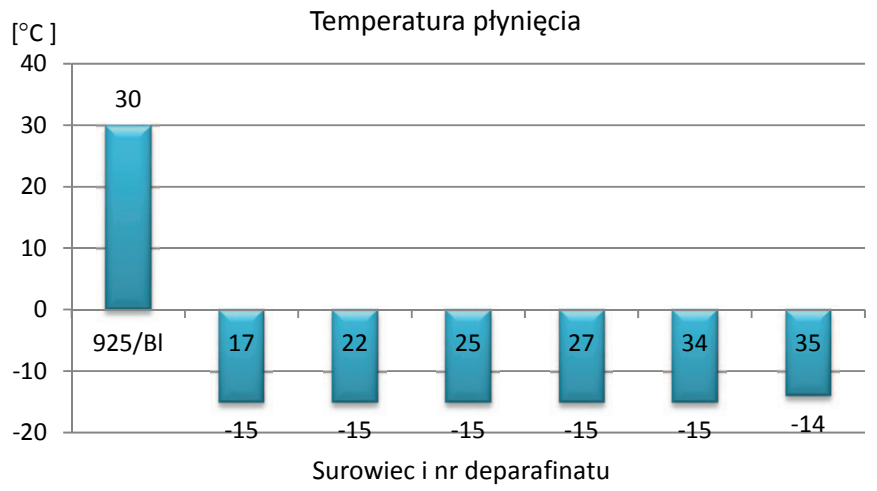

Rys. 2. Wpływ procesu odparafinowania rozpuszczalnikiem MEK-TOL na zmianę temperatury płynięcia deparafinatów 


\section{Wyniki badań odparafinowania rozpuszczalnikiem DI/ME plastyfikatora TDAE}

Procesy odparafinowania rozpuszczalnikiem DI/ME próbek surowca 925/B1 i 48/Bl przedstawiono w tablicy 5, gdzie przedstawione zostały też parametry technologiczne, bilans masowy oraz właściwości deparafinatów i gaczów uzyskanych z 6 procesów odparafinowania DI/ME próbki surowca 925/B1 i jednego odparafinowania próbki surowca 48/Bl.

Podstawowe parametry technologiczne były następujące: stosunek masowy DI/ME zawierał się w przedziale od 40:60 do $60: 40$, temperatura krystalizacji wynosiła $-18^{\circ} \mathrm{C}$ lub $-22^{\circ} \mathrm{C}$, całkowity stosunek rozpuszczalnika do frakcji wynosił od 6,5:1 do 11,7:1. W próbach nr 21 i 28 zastosowano do procesu modyfikator krystalizacji.
W próbach odparafinowania uzysk deparafinatu był duży i wynosił od 87,0 do $95,0 \%(\mathrm{~m} / \mathrm{m})$, a uzysk gaczu zawierał się w przedziale od 3,0 do $10,0 \%(\mathrm{~m} / \mathrm{m})$.

W porównaniu do surowca 925/B1 w wyniku procesu odparafinowania TDAE we wszystkich wykonanych próbach zaobserwowano w deparafinacie wzrost zawartości atomów węgla w strukturach aromatycznych, maksymalnie do $0,42 \%$ lub spadek do maksymalnie $0,3 \%$, zawartość atomów węgla w strukturach naftenowych wzrosła do maksymalnie $1,02 \%$ lub zmniejszała się do maksymalnie $1,85 \%$, natomiast zawartość atomów węgla w strukturach parafinowych zmniejszyła się do maksymalnie $1,06 \%$ lub wzrastała do maksymalnie $1,44 \%$.

Tablica 5. Parametry technologiczne, bilans masowy oraz właściwości deparafinatów i gaczów uzyskanych z procesów odparafinowania DI/ME próbek surowca 925/Bl i 48/B1

\begin{tabular}{|c|c|c|c|c|c|c|c|}
\hline $\mathrm{Nr}$ odparafinowania & 20 & 21 & 26 & 28 & 39 & 40 & 43 \\
\hline Surowiec, nr próbki & $925 / \mathrm{Bl}$ & 925/B1 & $925 / \mathrm{Bl}$ & $925 / \mathrm{Bl}$ & 925/B1 & 925/B1 & 48/B1 \\
\hline Modyfikator lepkości & - & $\begin{array}{l}\text { Viscoplex } \\
9-350\end{array}$ & - & $\begin{array}{l}\text { Viscoplex } \\
9-350\end{array}$ & - & - & - \\
\hline \multicolumn{8}{|c|}{ Parametry technologiczne procesów odparafinowania } \\
\hline Rozpuszczalnik Di/Me, stosunek mas. & $50: 50$ & $50: 50$ & $50: 50$ & $50: 50$ & $60: 40$ & $40: 60$ & $50: 50$ \\
\hline Temperatura krystalizacji/filtracji $\left[{ }^{\circ} \mathrm{C}\right]$ & -20 & -20 & -24 & -20 & -18 & -22 & -20 \\
\hline Całkowity stosunek rozpuszczalnika do frakcji & $11,7: 1$ & $11,7: 1$ & $6,5: 1$ & $6,5: 1$ & $6,5: 1$ & $6,5: 1$ & $11,7: 1$ \\
\hline Rozcieńczenie I, w temperaturze $60^{\circ} \mathrm{C}$ & $4,5: 1$ & $4,5: 1$ & $4,5: 1$ & $4,5: 1$ & $3,0: 1$ & $3,0: 1$ & $4,5: 1$ \\
\hline \multicolumn{8}{|c|}{ Bilans masowy procesów odparafinowania, wyniki uśrednione } \\
\hline Czas sączenia $[\mathrm{s}]$ & 144 & 74 & 39 & 45 & 51 & 43 & 48 \\
\hline Wydajność deparafinatu [\% $(\mathrm{m} / \mathrm{m})]$ & 95,0 & 95,0 & 87,0 & 93,0 & 94,0 & 91,0 & 94,0 \\
\hline Wydajność gaczu $[\%(\mathrm{~m} / \mathrm{m})]$ & 3,0 & 3,0 & 10,0 & 5,0 & 4,0 & 7,0 & 4,0 \\
\hline Straty $[\%(m / m)]$ & 2,0 & 2,0 & 3,0 & 2,0 & 2,0 & 2,0 & 2,0 \\
\hline \multicolumn{8}{|c|}{ Właściwości deparafinatu } \\
\hline Lepkość kinematyczna w temperaturze $10^{\circ} \mathrm{C}\left[\mathrm{mm}^{2} / \mathrm{s}\right]$ & 12584 & 12685 & 12815 & 12894 & 12894 & 12894 & 13067 \\
\hline $\begin{array}{l}\text { Lepkość kinematyczna w temperaturze } 100^{\circ} \mathrm{C} \\
{\left[\mathrm{mm}^{2} / \mathrm{s}\right]}\end{array}$ & 23,16 & 23,52 & 24,51 & 23,50 & 23,74 & 23,58 & 27,02 \\
\hline Współczynnik załamania światła $\mathrm{n}_{\mathrm{D}}^{20}$ & 1,5329 & 1,5328 & 1,5335 & 1,5324 & 1,5329 & 1,5326 & 1,5171 \\
\hline Gęstość w temperaturze $20^{\circ} \mathrm{C}\left[\mathrm{g} / \mathrm{cm}^{3}\right]$ & 0,9541 & 0,9575 & 0,9530 & 0,9532 & 0,9538 & 0,9536 & 0,9522 \\
\hline Zawartość siarki $[\%(\mathrm{~m} / \mathrm{m})]$ & 3,22 & 3,24 & 3,26 & 3,24 & 3,25 & 3,24 & 3,2 \\
\hline Zaw. WZA (ekstrakt DMSO) $[\%(\mathrm{~m} / \mathrm{m})]$ & 2,1 & 2,1 & 2,0 & 2,1 & 2,1 & 2,2 & 2,6 \\
\hline $\begin{array}{l}\text { Zawartość atomów węgla w strukturach [\%]: } \\
-\mathrm{C}_{\mathrm{A}} \\
-\mathrm{C}_{\mathrm{N}} \\
-\mathrm{C}_{\mathrm{P}}\end{array}$ & $\begin{array}{l}23,91 \\
20,16 \\
55,93 \\
\end{array}$ & $\begin{array}{l}23,85 \\
19,53 \\
56,62 \\
\end{array}$ & $\begin{array}{l}24,28 \\
17,29 \\
58,43 \\
\end{array}$ & $\begin{array}{l}23,56 \\
19,54 \\
56,89 \\
\end{array}$ & $\begin{array}{l}23,67 \\
19,42 \\
56,90 \\
\end{array}$ & $\begin{array}{l}23,72 \\
19,78 \\
56,50\end{array}$ & $\begin{array}{l}26,17 \\
16,97 \\
56,86 \\
\end{array}$ \\
\hline Temperatura płynięcia $\left[{ }^{\circ} \mathrm{C}\right]$ & -15 & -15 & -16 & -13 & -13 & -14 & -14 \\
\hline \multicolumn{8}{|c|}{ Właściwości gaczu } \\
\hline Współczynnik załamania światła $\mathrm{n}_{\mathrm{D}}{ }^{70}$ & 1,4549 & 1,4522 & 1,4830 & 1,4779 & 1,4643 & 1,4623 & 1,4748 \\
\hline Temperatura krzepnięcia $\left[{ }^{\circ} \mathrm{C}\right]$ & 58,7 & 58,0 & 52,8 & 55,6 & 56,1 & 56,4 & 53,4 \\
\hline Zawartość oleju [\% $(\mathrm{m} / \mathrm{m})]$ & 7,31 & 11,75 & 53,83 & 41,83 & 34,856 & 29,87 & 34,7 \\
\hline
\end{tabular}


We wszystkich próbach odparafinowania w deparafinacie nastąpiło znaczące obniżenie temperatury płynięcia, do przedziału od $-13^{\circ} \mathrm{C}$ do $-16^{\circ} \mathrm{C}$, w porównaniu do surowca, którego temperatura płynięcia wynosiła $+30^{\circ} \mathrm{C}$.

$\mathrm{Na}$ gaczach uzyskanych w próbach odparafinowania wykonano badania trzech parametrów jakościowych.

W porównaniu do deparafinatów i surowca w gaczach wyraźnie zmniejszyła się wartość współczynnika załamania światła oraz wyraźnie wzrosła temperatura krzepnięcia, co wskazuje na zachowanie selektywności procesu odparafinowania rafinatu TDAE.

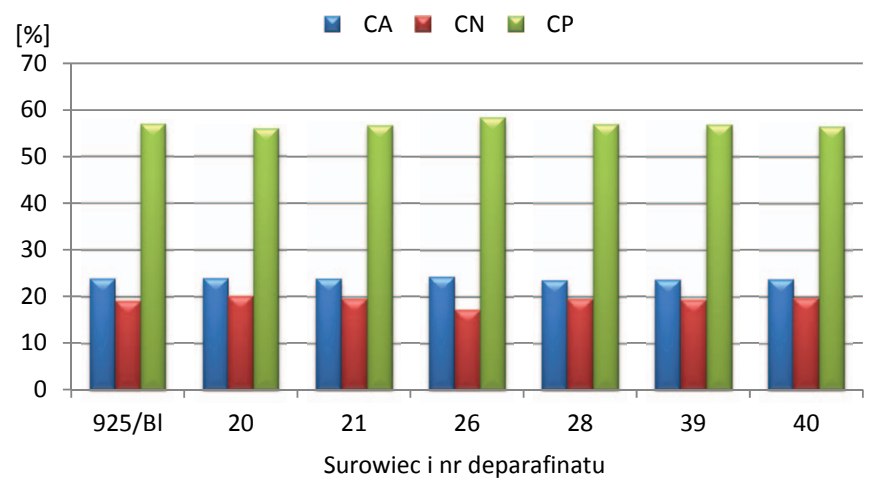

Rys. 3. Wpływ procesu odparafinowania rozpuszczalnikiem DI/ME na zmianę składu strukturalnego deparafinatów
W jednej próbie odparafinowania surowca 48/Bl uzysk deparafinatu wynosił $94,0 \%(\mathrm{~m} / \mathrm{m})$, a uzysk gaczu $4,0 \%(\mathrm{~m} / \mathrm{m})$.

W porównaniu do surowca 48/B1 w wyniku procesu odparafinowania w deparafinacie TDAE zaobserwowano wzrost zawartości atomów węgla w strukturach aromatycznych - wynosił $0,33 \%$. W deparafinacie nastąpiło znaczące obniżenie temperatury płynięcia, do $-14^{\circ} \mathrm{C}, \mathrm{w}$ porównaniu do surowca (plastyfikatora TDAE).

Ilustrację graficzną wpływu procesu odparafinowania dla wsadu 925/Bl na zmianę składu strukturalnego i temperatury płynięcia deparafinatów przedstawiono na rysunkach 3-4.

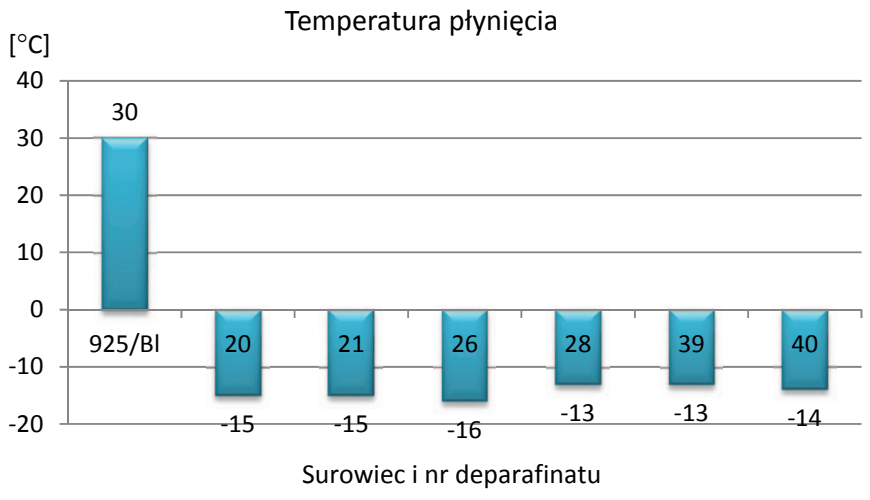

Rys. 4. Wpływ procesu odparafinowania rozpuszczalnikiem DI/ME na zmianę temperatury płynięcia deparafinatów

\section{Podsumowanie}

Plastyfikatory naftowe znalazły zastosowanie jako jeden z istotnych składników wyrobów kauczukowych i gumowych. Funkcja zmiękczaczy mineralnych polega między innymi na modyfikacji właściwości fizycznych wyrobów gumowych, szczególnie poprzez poprawę wytrzymałości na rozciąganie, twardości, rozdzierności oraz elastyczności w niskich temperaturach. Klasyczne plastyfikatory naftowe TDAE charakteryzują się dodatnią temperaturą płynięcia, co jest cechą mogącą wpływać niekorzystnie na elastyczność wyrobów gumowych w niskich temperaturach. Wpływ plastyfikatorów naftowych na właściwości wyrobów gumowych w niskich temperaturach oraz próba poprawy składu strukturalnego węglowodorów były inspiracją do badań procesu odparafinowania klasycznego plastyfikatora TDAE.

Poddanie procesowi rozpuszczalnikowego odparafinowania wsadu (surowca) zawierającego inne niż klasyczne wsady grupy związków węglowodorowych, o skomplikowanej mieszanej strukturze, bardziej polarnych związków parafinowo-naftenowych, aromatycznych i żywic oraz - co ważne - z niewielką zawartością związków posiadających długie łańcuchy n-parafinowe, można uznać za oryginalne rozwiązanie. Węglowodory n-parafinowe są podstawowym składnikiem usuwanym z wsadu w klasycznym odparafinowaniu rozpuszczal- nikowym i są głównym składnikiem ubocznego produktu tego procesu, jakim jest gacz parafinowy.

Takim nieklasycznym surowcem jest typowy plastyfikator TDAE o dodatnich temperaturach płynięcia.

Przeprowadzone badania procesu odparafinowania rozpuszczalnikowego dwóch różnych plastyfikatorów TDAE nie doprowadziły do wyraźnej poprawy składu strukturalnego węglowodorów. W większości prób odparafinowania rafinatów plastyfikatorów nie uzyskano korzystnej zmiany składu strukturalnego węglowodorów, zwłaszcza jeśli chodzi o zwiększenie zawartości atomów węgla w strukturach aromatycznych w porównaniu $\mathrm{z}$ wsadem do odparafinowania. W próbach odparafinowania plastyfikatora nie otrzymano również korzystnej zmiany składu strukturalnego węglowodorów - zawartość atomów węgla w strukturach aromatycznych maksymalnie wyniosła $26,21 \%$, co dało wzrost atomów węgla w strukturach aromatycznych poniżej $1 \% \mathrm{w}$ stosunku do wsadu. Podobnie zawartość atomów węgla w strukturach naftenowych w przypadku części prób odparafinowania niewiele rośnie, a w innych próbach maleje w porównaniu do surowca. Również zawartość atomów węgla w strukturach parafinowych niewiele maleje lub rośnie w porównaniu do surowca, a pożądane byłoby, aby zawartość parafin istotnie zmniejszyła się, 
poprawiając zawartość przede wszystkim związków aromatycznych. Reasumując, proces rozpuszczalnikowego odparafinowania mieszaninami MEK-TOL i DI/ME zastosowany do surowca typu plastyfikator TDAE powoduje niewielkie przesunięcia w składzie strukturalnym deparafinatu w porównaniu do surowca i nie daje istotnej poprawy pożądanej aromatycznej struktury rafinatów TDAE.

W przedstawionej ocenie składu strukturalnego węglowodorów należy jednak pamiętać, że skład strukturalny według normy ASTM D 2410 [7] jest obliczany w pośredni sposób poprzez oznaczenie lepkości, gęstości, współczynnika załamania światła, obliczenie wartości stałej lepkościowo-gęstościowej i interceptu refrakcji, a następnie odczytanie składu z nomogramu oraz wzoru obliczeniowego korygującego skład, z uwzględnieniem zawartości siarki, i może nie do końca odzwierciedlać rzeczywistą zmianę strukturalną węglowodorów po procesie odparafinowania.
Okazuje się, że odparafinowanie rozpuszczalnikowe plastyfikatora TDAE o dodatnich temperaturach płynięcia, spełniającego wymagania rozporządzenia 1907/2006 UE, zachowuje jednak dobrą selektywność procesu i pozwala na duże obniżenie temperatury płynięcia plastyfikatora, co ma wpływ na poprawienie właściwości reologicznych i niskotemperaturowych.

We wszystkich wykonanych próbach odparafinowania w deparafinacie nastąpiło znaczące obniżenie temperatury płynięcia, do przedziału od $-13^{\circ} \mathrm{C}$ do $-16^{\circ} \mathrm{C}$, w porównaniu do dodatnich temperatur płynięcia surowców. Uzyskany efekt obniżenia temperatury płynięcia plastyfikatora TDAE $w$ procesie odparafinowania rozpuszczalnikowego z jednoczesnym zachowaniem parametrów jakościowych spełniających wymagania rozporządzenia REACH można ocenić jako wytworzenie zmodyfikowanego plastyfikatora TDAE o ujemnej temperaturze płynięcia, który powinien mieć wpływ na poprawę właściwości użytkowych wyrobów gumowych w niskich temperaturach.

Prosimy cytować jako: Nafta-Gaz 2018, nr 1, s. 49-60, DOI: 10.18668/NG.2018.01.06

Artykuł nadesłano do Redakcji 13.11.2017 r. Zatwierdzono do druku 28.12.2017 r.

Artykuł powstał na podstawie pracy statutowej pt.: Ocena procesu odparafinowania rozpuszczalnikowego plastyfikatora TDAE praca INiG - PIB na zlecenie MNiSW; nr zlecenia: 0044/TO/16, nr archiwalny: DK-4100-/44/16, oraz pracy statutowej pt.: Ocena wplywu plastyfikatora TDAE na wymagania jakościowe wyrobów gumowych - praca INiG - PIB na zlecenie MNiSW; nr zlecenia: 0093/TO/17, nr archiwalny: DK-4100-/80/17.

\section{Literatura}

[1] Aman-Alikhani M., Taghvaei Ganjali S.: The influence of noncarcinogenic petroleum-based process oils on tire compounds' performance. Iran Polymer and Petrochemical Institute 2013.

[2] Bartyzel A.: Badanie selektywności rozpuszczalników organicznych stosowanych $w$ procesach ciagtej ekstrakcji rozpuszczalnikowej wysokoaromatycznych olejów naftowych. Nafta-Gaz 2012, nr 10, s. 693-698.

[3] Ptak S.: Ocena procesu odparafinowania rozpuszczalnikowego plastyfikatora TDAE. Nafta-Gaz 2017, nr 8, s. 605-615, DOI: 10.18668/NG.2017.08.08.

[4] Ptak S.: Plastyfikatory naftowe dla przemystu gumowego - odparafinowanie plastyfikatora TDAE. Nafta-Gaz 2017, nr 9, s. 675-684, DOI: 10.18668/NG.2017.09.07.

[5] Steinmec F., Bartyzel A.: Aromatyczne plastyfikatory naftowe dla przemystu gumowego. [W:] W. Parasiewicz, W.M. Rzymski (red.): Elastomery i przemyst gumowy: praca zbiorowa, Piastów-Lódź 2006.

[6] Tonkonogov B.P., Os'mushnikov V.A., Karimova A.F.: Use of environmentally friendly plasticizers, obtained, by propane deasphalting, in tire rubbers. Chemistry and Technology of Fuels and Oils 2015, vol. 50, no. 6, s. 475-482.

\section{Akty prawne i normatywne}

[7] Norma ASTM D 2410:2015 Standard Test Method for CarbonType Composition of Insulating Oils of Petroleum Origin.

[8] Patent DE 234323 Verfahren zur behandlung von mineral schmieroel-ausgangs materialien. British Petroleum Co., z dnia 14.03.1974.

[9] Patent DE 2753163 Verfahren und vorrichtung zur abtrennung von festem paraffin aus erdoel. Texaco Development Corp., $\mathrm{z}$ dnia 15.06.1978.

[10] Patent DE 2827494 Verfahren zur entparaffinierung von paraffinhaltigem schmieroel ausgangs material. Texaco Development Corp., z dnia 25.01.1979.

[11] Patent DE 3930422 Process for the production of process oils with a low content of polycyclic aromatic compounds. BP oiltech GmbH, z dnia 21.03.1991.

[12] Patent EP 1106673 Removal of polycyclic aromatic compounds from extracts. Shell Int. Research, z dnia 13.06.2001.

[13] Patent EP 1260569 Process for making non-carcinogenic, high aromatic process oil. Shell Int. Research, z dnia 27.11.2002.

[14] Patent EP 839891 Process for obtaining aromatic oils having a polycyclic aromatics content of less than $3 \%$ which are useful as process oils. Repsol Petroleo SA, z dnia 6.05.1998.

[15] Patent GB 1155695 Process and apparatus for the Recovery of Solvents used in Dewaxing Mineral Oils and the like. Edeleanu $\mathrm{GmbH}, \mathrm{z}$ dnia 18.06.1969.

[16] Patent PL 141875 Sposób odparafinowania olejów. Instytut Nafty i Gazu, z dnia 3.06.1986.

[17] Patent PL 151667 Sposób odparafinowania olejów za pomoca rozpuszczalników. Instytut Nafty i Gazu, z dnia 29.03.1991.

[18] Patent PL 161658 Sposób odolejania gaczów parafinowych za pomoca rozpuszczalników. Instytut Nafty i Gazu, z dnia 30.07.1993.

[19] Patent PL 162782 Sposób rozpuszczalnikowego odparafinowania olejów naftowych z zastosowaniem dodatku modyfikujacego proces krystalizacji parafiny. Instytut Nafty i Gazu, z dnia 27.01.1992. 
[20] Patent PL 188731 Sposób odparafinowania olejów. Instytut Nafty i Gazu, z dnia 29.04.2005.

[21] Patent PL 207051 Sposób wytwarzania plastyfikatora naftowego do kauczuku i gumy. Instytut Nafty i Gazu, Grupa LOTOS S.A., z dnia 29.10.2010.

[22] Patent PL 207052 Sposób wytwarzania plastyfikatora TDAE do kauczuku i gumy. Instytut Nafty i Gazu, Grupa LOTOS S.A., z dnia 29.10.2010.

[23] Patent PL 207056 Sposób wytwarzania plastyfikatora TDAE. Instytut Nafty i Gazu, z dnia 29.10.2010.

[24] Patent PL 208531 Plastyfikator i sposób wytwarzania plastyfikatora. Zakrytoe Aktsionernoe Obschestvo Torgovy Dom „Orgkhim”, z dnia 31.05.2011.

[25] Patent PL 224956 Sposób wytwarzania plastyfikatora naftowego do kauczuku i gumy. Instytut Nafty i Gazu, Grupa LOTOS S.A., z dnia 28.02.2017.

[26] Patent US 3972779 Means for controlling dewaxing apparatus. Texaco Inc., z dnia 3.08.1976.

[27] Patent US 4146461 Dilution chilling dewaxing by modification of tower temperature profile. Exxon Research Engineering Co., $\mathrm{z}$ dnia 27.03.1979.

[28] Patent US 4375403 Solvent dewaxing process. Texaco Inc., z dnia 1.03.1983.

[29] Patent US 4444648 Solvent dewaxing with methyl tertiary butyl ether. Exxon Research Engineering Co., z dnia 24.04.1984.

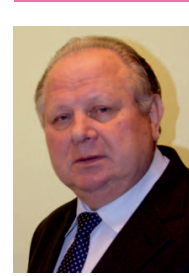

Prof. dr hab. inż. Janusz JAKÓBIEC

Profesor zwyczajny

Wydział Energetyki i Paliw,

Katedra Technologii Paliw

Akademia Górniczo-Hutnicza

al. Mickiewicza 30, 30-059 Kraków

E-mail:jjakobie@agh.edu.pl
[30] Zgłoszenie patentowe EP 3031621 A1 Pneumatic tire. The Goodyear Tire \& Rubber Company, z dnia 9.12.2014.

[31] Zgłoszenie patentowe US 2015/0152253 A1 FunctionalizedESBR with acrylate functional base group. Synthos S.A., z dnia 22.02.2012.

[32] Zgłoszenie patentowe WO2011098096 A1 Method for producing process oils having a low content of polycyclic aromatics and use thereof. H \& R International GmbH, z dnia 10.02.2010.

[33] Rozporządzenie (WE) nr 1907/2006 Parlamentu Europejskiego i Rady z dnia 18 grudnia 2006 r. w sprawie rejestracji, oceny, udzielania zezwoleń i stosowanych ograniczeń w zakresie chemikaliów (REACH) (Dz.Urz. UE L 396 z 30.12.2006, z późn. zm.).

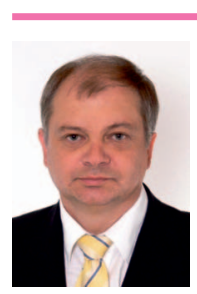

Mgr inż. Stefan PTAK

Główny specjalista inżynieryjno-techniczny;

kierownik Zakładu Olejów, Środków Smarowych i Asfaltów.

Instytut Nafty i Gazu - Państwowy Instytut Badawczy ul. Lubicz 25 A, 31-503 Kraków

E-mail:stefan.ptak@inig.pl

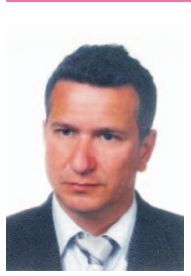

Mgr inż. Artur ANTOSZ

Starszy specjalista badawczo-techniczny w Zakładzie Olejów, Środków Smarowych i Asfaltów.

Instytut Nafty i Gazu - Państwowy Instytut Badawczy ul. Lubicz $25 \mathrm{~A}$

31-503 Kraków

E-mail: artur.antosz@inig.pl 